\title{
Detection of the Protease Inhibitor (Pi) Systems of the Light Breed Horses by Isoelectric Focusing
}

Michinari Yokohama and Kazushige Mogr

Laboratory of Racing Chemistry, Setagaya-ku 158

(Received March 14, 1985)

\begin{abstract}
Detection of the equine protease inhibitor (Pi) systems was carried out by isoelectric focusing (IEF) with a high capacity for resolution and repeatability. The $\mathrm{Pi}$ systems of the light breed horses were classified and their usefulness as marker genes for parentage testing was discussed. 1. To increase resolution of Pi electrophoretic patterns, serum samples were treated with a reducing agent and a separating agent was added to the polyacrylamide gels. Consequently, $\mathrm{Pi}$ bands could be detected more clearly because of increased separation detween $\mathrm{Pi}$ and $\mathrm{Pa}$ regions, and made it possible to remove any extra proteins. New attached bands in $\mathrm{Pi}$ systems could then be detected in the regions which has been called $\mathrm{Xc} / \mathrm{Xd} / \mathrm{Xh}$. 2. It became apparent that the $\mathrm{Pi}$ types in the light breed horses are controlled by eleven codominant autosomal alleles; $P i^{F}$, $P i^{G}, P i^{I}, P i^{L}, P i^{L 1}, P i^{M}, P i^{N}, P i^{S 1}, P i^{S 2}, P i^{U}$ and $P i^{Z}$. The $P i^{L}$ allele was found to have the highest frequency of $44.7 \%$ in the light breed horses. 3 . As the theoretical paternity exclusion probability of $\mathrm{Pi}$ system was 0.532 , it was recognized that the system could be very useful as the marker gene for parentage testing in the light breed horses.

Jpn. J. Zootech. Sci., $56(11): 883-888,1985$
\end{abstract}

Key words : Light breed horse, Protease inhibitor system, Isoelectric focusing

The equine prealbumin system (Pre) was first reported by Ganne (1966) 1). Subsequently, the electrophoretic methods used for determination of Pre types were improved, and Pre types were studied in many kinds of horses. It became apparent that Pre system is controlled by a minimum of 15 codominant autosomal alleles; $\operatorname{Pr}^{D 1}$, Pre $^{D 2}, \operatorname{Pr}^{F}$, Pre $^{G}$, Pre $^{I}$, Pre $^{L}$, Pre $^{L 1}$, Pre $^{M}$, Pre $^{N}$, Pre $^{S}$, Pre $^{T}$, Pre $^{U}$, Pre $^{W}$, $\operatorname{Pre}^{Z}$, and $\operatorname{Pr} e^{Y 2,3,4)}$.

On the basis of studies by EK (1979) ${ }^{5}$, MAtThEWs $(1979)^{6)}$ and JUNEJA et al. $(1979)^{7)}$, it was found that Pre protein corresponds to human Pi protein, with regard to its antitrypsin activity, electrophoretic mobility and molecular weight. As the $\alpha-$ protease inhibitor activities of Pre bands described above were also confirmed, it was suggested that Pre system should be renamed as $\mathrm{Pi}$ system. Since the system has subsequently been used as $\mathrm{Pi}$ system, it should be referred to as such in the present paper.

JUNEJA et al. ${ }^{7)}$ have also analyzed equine Pi types by means of two-dimensional gel electrophoresis, and two groups of $\alpha_{1}$-globulin designated $\mathrm{Pi} 1$ and $\mathrm{Pi} 2$, for which complete genetic linkage was observed, were found to be protease inhibitors. It was shown that the Pi protein has a high heterogeneity. 
At present, there is a problem in that the results obtained for the $\mathrm{Pi}$ system in each laboratory which participated in the horse blood typing comparison test did not correspond as compared with those of other systems. This might be due to differences in the electrophoresis technics and multiplicity of Pi protein zones. However, as ScotT $(1976)^{8)}$ mentioned, since $P i$ locus had a high polymorphism; it was thought that $\mathrm{Pi}$ system could be the most useful one as a marker gene for the identification and parentage test.

This report presents the results of examining the detection of equine $\mathrm{Pi}$ types by isoelectric focusing (IEF) with a high capacity for resolution and repeatabilty. At the same time, the $\mathrm{Pi}$ types of the light breed horses were classified and their usefulness as the marker gene for parentage testing was also studied.

\section{Materials and Methods}

Sera used: Serum samples were obtained from 2501 horses consisting of Thoro. ughbreds (1514), Anglo-Arabs (979) and Arabs (8). The serum samples were treated with $100 \mathrm{mg} / 2.56 \mathrm{ml}$ dithiothreitol in distilled water and $4.6 \mathrm{mg} / 2 \mathrm{~m} l$ iodoacetoamide in distilled water in a $2: 1: 2$ ratio overnight at $4^{\circ} \mathrm{C}$.

Making of gels: Gels were made according to the method reported by Үоконама et al. ${ }^{9}$, except that $0.4 \mathrm{ml}$ of Pharmalyte (Pharmacia) $4-6.5$ and $0.3 \mathrm{ml}$ of SERVALYT (SERVA) AG 4-5 were used as the carrier ampholyte, with 117. $3 \mathrm{mg}$ of ACES (Sigma) added the stock solution per a gel plate.

Electrophoresis: Contacts of gel with anode and cathode were made using strips of TOYO No. 526 filter paper soaked in $0.04 \mathrm{M} \mathrm{DL}$-glutamic acid and $0.2 \mathrm{M} \mathrm{L}-$ histidine, respectively. Running was carried out initially at $450 \mathrm{~V}(2.5 \mathrm{~W})$ and finally at $1200 \mathrm{~V}$ for 4.5 hours. The sample papers (TOYO No. 526 filter paper measuring $4 \mathrm{~mm} \times 5 \mathrm{~mm}$ ) were removed after 15 minutes of running.

Fixing and staining: Gels were fixed and stained according to the method reported by YoKoHama et al.9).

Genetical analysis: 707 pairs of family data were used studying the inheritance of Pi types.

Exclusion probabilities: The theoretical paternity exclusion probabilities were calculated by the method of RENDEL and WINER et al. ${ }^{10,11)}$, and then the practical exclu* sion probabilities were studied by using 340 pairs of parentage cases of two sires offered for the parentage test.

\section{Results and Discussion}

Fig. 1 shows the electrophoretic patterns of Pi phenotypes which were detected by the IEF method. As can be seen, the patterns on the gel were separated into three regions, $\mathrm{Pi}$ (Pre), $\mathrm{Xc} / \mathrm{Xd} / \mathrm{Xh}$ and $\mathrm{Pa}(\mathrm{Xk})$ regions, which were the same as those of acidic prealbumin types reported by BRAEND ${ }^{12.13}$. Compared with the equine Pi types determined by IEF which were first reported by Matrhews (1979) ${ }^{14}$, the IEF method reported here differed in several ways. Namely, before running, serum 


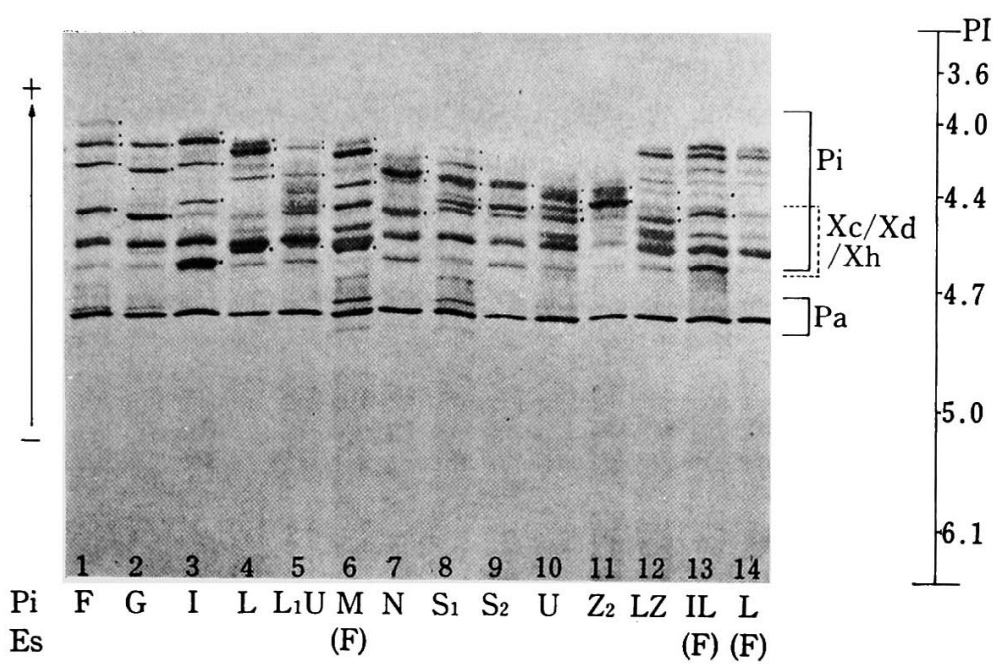

Fig. 1. Electrophoretic patterns of the equine $\mathrm{Pi}$ and $\mathrm{Pa}$ systems by IEF.

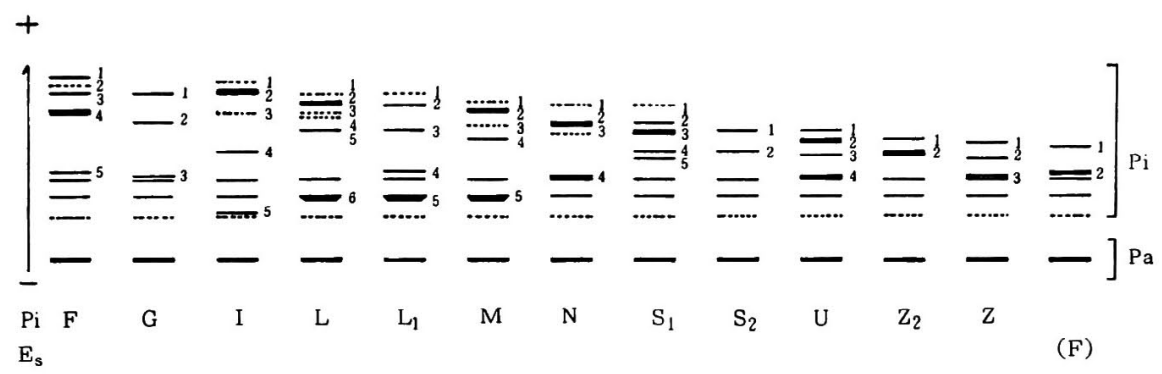

Fig. 2. Diagram to illustrate $\mathrm{Pi}$ and $\mathrm{Pa}$ phenotypes

samples were treated with a reducing agent, and then a separating agent was added to the gel solution. Consequently, extra proteins on $\mathrm{Pi}$ zones were removed and the separation between $\mathrm{Pi}$ and $\mathrm{Pa}$ regions was increased, making it possible to distinguish Pi bands more clearly.

As shown in the photograph in Fig. 1, 12 basic bands (F, G, I, L, L $, M, N$, $S_{1}, S_{2}, U, Z_{2}$ and $Z$ ) of $\mathrm{Pi}$ could be classified by the IEF method reported here, although the No. 11 individual with $Z_{2}$ type was taken from the samples of the 1983 horse blood typing comparison test. As individuals Nos. 6, 13 and 14 were shown to be $\mathrm{M}-(\mathrm{F}), \mathrm{IL}-(\mathrm{F})$ and $\mathrm{L}-(\mathrm{F})$ types, respectively, which were contained $\mathrm{F}$ band of Es system was detected within $\mathrm{Pi}$ zones.

Fig. 2 shows a diagram of each Pi type. As can be seen, the bands in each $\mathrm{Pi}$ type were shown by assigning arabic figures to then in order of decreasing electrophoretic mobility. The patterns of $\mathrm{L}$ and $\mathrm{L}_{1}$ types resembled each other, except for the fact that $L_{1}$ type did not have Nos. 3 and 4 bands shown by $L$ type, and that No. 4 band absent from $L$ type was observed in $L_{1}$ type. In $I, L, L_{1}$ and $M$ types, new attached bands which were named Nos. 5, 6, 5 and 4, respectively, were de- 
tected in $\mathrm{Xc} / \mathrm{Xd} / \mathrm{Xd}$ region, anh these attached bands were available for use as markers for classifying Pi types.

The segregation ratios of $\mathrm{Pi}$ types except for the $Z_{2}$ type were studied using the results of 707 pairs of matings. Consequently, it was reconfirmed that $\mathrm{Pi}$ types were controlled by a pair of codominant autosomal alleles at a single locus.

Table 1. Gene frequencies of $\mathrm{Pi}$ system in the light breed horses

\begin{tabular}{ccccc} 
& & & & \\
Alleles & Thoroughbreds & Anglo-Arabs & Arabs & \multirow{2}{*}{ Average } \\
\cline { 2 - 4 } & 0.036 & 0.092 & 0.188 & 0.059 \\
$P i^{F}$ & 0.007 & 0.058 & 0. & 0.027 \\
$P i^{G}$ & 0.065 & 0.079 & 0.188 & 0.071 \\
$P i^{I}$ & 0.466 & 0.420 & 0.250 & 0.447 \\
$P i^{L}$ & 0.011 & 0.009 & 0. & 0.010 \\
$P i^{L 1}$ & 0. & 0.024 & 0. & 0.009 \\
$P i^{M}$ & 0.196 & 0.098 & 0. & 0.157 \\
$P i^{N}$ & 0.034 & 0.055 & 0.313 & 0.043 \\
$P i^{S 1}$ & 0.054 & 0.059 & 0.063 & 0.056 \\
$P i^{S 2}$ & 0.127 & 0.106 & 0. & 0.118 \\
$P i^{U}$ & 0.003 & 0.001 & 0. & 0.002 \\
$P i^{2}$ & 1514 & 979 & 8 & 2501 \\
\hline
\end{tabular}

Table 2. Estimation of the average probability of negating one of the two possible sires in parentage cases

\begin{tabular}{|c|c|c|c|c|}
\hline \multirow{2}{*}{ Loci } & \multirow{2}{*}{ No. of alleles } & \multicolumn{2}{|c|}{ Breeds } & \multirow{2}{*}{ Average } \\
\hline & & Thoroughbreds & Anglo-Arabs & \\
\hline Red cell loci alone* & & 0.454 & 0.458 & 0.460 \\
\hline$T f$ & 5 & 0.421 & 0.430 & 0.429 \\
\hline$A l b$ & 2 & 0.143 & 0.172 & 0.160 \\
\hline Es & 3 & 0.118 & 0.128 & 0.126 \\
\hline$P i$ (S. G. E.) & 4 & 0.120 & 0.196 & 0.160 \\
\hline $6-P G D$ & 2 & 0. 183 & 0.185 & 0. 183 \\
\hline$H b-a \quad(\mathrm{IEF})$ & 2 & 0.112 & 0.126 & 0.117 \\
\hline 12 loci combined & & 0.847 & 0.872 & 0.862 \\
\hline$P i$ (IEF) & 11 & 0.522 & 0.581 & 0.532 \\
\hline$P a \quad$ (IEF) & 2 & 0 & 0.026 & 0.016 \\
\hline $\begin{array}{l}13 \text { loci combined } \\
\text { which added } P i \\
\text { and } P a \text { (IEF) } \\
\text { instead of } P i \\
\text { (S. G. E.) }\end{array}$ & & 0.917 & 0.935 & 0.925 \\
\hline
\end{tabular}

*: The case that genotype of sire is not clear, and 6 loci are A, C, D, P, Q and U systems. 
Table 3. Number and percentage of negating one of two possible sires when Pi system (IEF) was adopted for parentage test

\begin{tabular}{|c|c|c|c|c|c|}
\hline \multirow{2}{*}{ Items studied } & \multicolumn{2}{|c|}{$\begin{array}{l}\text { Case that genotype of dam was } \\
\text { clear }\end{array}$} & \multicolumn{2}{|c|}{$\begin{array}{l}\text { Case that genotype of dam was } \\
\text { not clear }\end{array}$} & \multirow{2}{*}{ Average } \\
\hline & Thoroughbreds & Anglo Arabs & Thoroughbreds & Anglo-Arabs & \\
\hline No. of parentage cases & 231 & 36 & 52 & 21 & 340 \\
\hline $\begin{array}{l}\text { Parentage cases solved } \\
\text { by } \mathrm{Pi} \text { system }(\mathrm{S} . \mathrm{G} . \mathrm{E} \text {.) }\end{array}$ & $\begin{array}{l}(11) \\
0.048\end{array}$ & $\begin{aligned}(7) \\
0.194\end{aligned}$ & $\begin{array}{r}(3) \\
0.058\end{array}$ & $\begin{array}{r}(2) \\
0.095\end{array}$ & $\begin{array}{c}(23) \\
0.068\end{array}$ \\
\hline $\begin{array}{l}\text { Parentage cases solved } \\
\text { by } \mathrm{Pi} \text { system (IEF) }\end{array}$ & $\begin{array}{l}(100) \\
0.433\end{array}$ & $\begin{array}{l}(21) \\
0.583\end{array}$ & $\begin{array}{r}(18) \\
0.346\end{array}$ & $\begin{array}{r}(5) \\
0.238\end{array}$ & $\begin{array}{l}(144) \\
0.424\end{array}$ \\
\hline
\end{tabular}

( ) : No. of animals, S. G. E. : Starch gel electrophoresis, IEF: Isoelectric focusing.

If it is accepted that $\mathrm{Pi}$ system consists of eleven codominant autosomal alleles, then 66 different genotypes should theoretically be possible. However, only 56 genotypes were observed in this study using 2501 light breed horses.

Table 1 shows the results of gene frequencies of $P i$ alleles in the light breed horses. Differences in the frequencies were not extreme between Thoroughbreds and Anglo-Arabs. Howevere, whereas $P i^{m}$ allele was not recognized in the former, its frequency was $2.4 \%$ in the latter, while $P^{N}$ allele was about $10 \%$ higher than that of the latter. Also $P i^{M}$ allele was found to correspond with $P e^{S}$ allele which was first classified by GAHNE ${ }^{1 \text { ? }}$.

Table 2 shows the results obtained for the theoretical paternity exclusion probabilities of $\mathrm{Pi}$ and $\mathrm{Pa}$ systems along with 12 loci. It can be seen that the exclusion probabilities of $\mathrm{Pi}$ types in Thoroughbreds and Anglo-Arabs were 52.2 and $58.1 \%$, respectively. Their values were the highest as compared with other loci. The exclusion probabilities of the 13 loci including $\mathrm{Pa}$ system that can be detected along with $\mathrm{Pi}$ types were $93 \%$ in the light breed horses used. This figure could be expected to increased by about $6 \%$ when the 13 loci have been adapted for the blood typing.

Table 3 shows the results obtained when the practical exclusion probabilities of $\mathrm{Pi}$ system were studied by using the parentage cases of the two sires which were of fered for the parentage test. In Thoroughbreds, eleven (4.8\%) of 231 parentage cases could be solved using Pre $(\mathrm{Pi})$ types by means of starch gel electrophoresis, whereas by using $\mathrm{Pi}$ types detected by IEF, $100(43.3 \%)$ of these cases could be solved. In Anglo-Arabs, using the former types, seven (19.4\%) of 36 parentage cases could be solved, whereas 21 cases (58.3\%) could be solved using the latter types. Accordingly. it was recognized that $\mathrm{Pi}$ types characterised by means of IEF were considerably useful as marker genes in the parentage test. But, if we introduce this $\mathrm{Pi}$ system to routine works, we should have to check for by means of twodimentional electrophoresis some $\mathrm{Pi}$ types whether they are heterozygotes or not.

\section{Acknowledgements}

This work was sponsored by the Japan Racing Association. 


\title{
References
}

1) Gahne, B., Genetics, 53: 681-694, 1966.

2) Braend, M., Acta vet. scand,, 23: 592-602. 1982.

3) Braend, M., Genetics, 68: 495-503. 1970.

4) Scort, A. M., Anim. Blood Grps biochem. Genet. (Suppl. 1), 19. 1979.

5) Ek, N., Acta vet. scand., 20: 180-190. 1979.

6) Matthews, A. G., Equine vet. J., 11: 177-182. 1979.

7) Juneja, R. K., B. Gahne and K. Sandberg, Anim. Blood Grps biochem. Genet., 10: 235251. 1979.

8) Scort, A. M., Proc. 4th Int. Conf. Equine Infections Dis. (Lyons, 1976). Veterinary Publishers, New Jersey, pp. 259-268.

9) Yokohama, M., Y. Watanabe and K. Mogi, Jpn. J. Zootech. Sci., 56: 116-121. 1985.

10) Rendel, J., Acta Agric. scand., 8: 131-161. 1958.

11) Winer, A. S., M. Lender and S. H. Polayes, J. Immunology, 19: 259-282. 1930.

12) Braend, M., Acta vet. scand., 8: 193-194. 1967.

13) BraEnd, M., Genetics, 65: 495-503. 1970.

14) Matrhews, A. G., Anim. Blood Grps. biochem. Genet., 10: 219-226. 1979.

15) Үоконамa, M., Mog1 and S. Suzuki, ABRI, No, 11: 43-46. 1983.

\section{等電点電気泳動法による軽種馬の $\mathrm{Pi}$ system}

\author{
横浜道成・茂木一重 \\ 競走馬理化学研究所, 東京都世田谷区 158
}

再現性および分析能が高い等電点電気泳動法 (IEF) に上る Protease inhibitor (Pi) 型の㭘出法の榆討老行 らと同時に，軽種馬に特けるPi 型の分類敊よびその標 識遗伝子としての有効性を調べた結果，次の如く成績が 得られた。

1. Pi 型の泳動像をより鮮明にするため還元剂によ

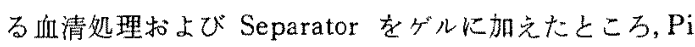
域と $\mathrm{Pa}$ 域間が拡大でき，さらに余分な蛋白の除去も可 能となったため, 各 $\mathrm{Pi}$ 型バンドがより鮮明に検出でき た。立た欲来から Xc/Xd/Xhと呵ばれている域にPi 型
の新しいバンドが検出できた.

2. IEF 法により検出された軽種馬の $\mathrm{Pi}$ 型は $P i F$, $P i^{G}, P i^{I}, P i^{L}, P i^{L 1}, P i^{M}, P i^{N}, P i^{S 1}, P i^{\mathrm{Sa}}, P i^{U}$ 扰上 び $P i^{Z} の 11$ 種類の対立遣后子から成ることが分かった. また，PiL の頻度が $44.7 \%$ と最も高い値でめった。

3. 軽種馬のPi 型における理論的な父権否定の確率 は0.532で，親子判定上きわ力て有効な標識遗伝子“゙゙あ ることが喼められた。

日蓄会報，56(11)：883-888，1985 